\title{
Reality and Obstacles of the Partnership between Family and School in Jordan
}

\author{
Suad Fayez Malkawi ${ }^{1} \&$ Mohammed Amin Hamid Al-Qudah ${ }^{2}$ \\ ${ }^{1} \mathrm{PhD}$ Applicant in Education Foundation, Faculty of Educational Sciences, University of Jordan, Amman, \\ Jordan \\ ${ }^{2}$ Prof. in Education Foundations, Faculty of Educational Sciences, University of Jordan, Amman, Jordan \\ Correspondence: Prof. "Mohammed Amin" Hamid Al-Qudah, University of Jordan - Faculty of Educational \\ Sciences, Foundation of Education, Amman, Jordan. Tel: 962-79-5229899. E-mail: m.amin.qudah@gmail.com, \\ mo.qudah@ju.edu.jo, suad.malkawi1@gmail.com
}

Received: December 21, 2017

Accepted: January 5, $2018 \quad$ Online Published: January 19, 2018

doi:10.5539/mas.v12n2p81

URL: https://doi.org/10.5539/mas.v12n2p81

\begin{abstract}
The study aimed at identifying the reality and obstacles of the partnership between the family and the school in Jordan (Qualitative Study). The study adopted the qualitative approach based on interviews with the school principals and parents participating in the Parents' Councils in Jordan, a total of 30 interviews have been made for this study: 9 interviews with the school principals and 21 others with parents.

The study resulted on a moderate level of partnership between the family and the school in Jordan and this is for both school administrators and parents, however and as for the obstacles of partnership between the family and the school, the result was a bit different; the school administrators believe that the external obstacle originating from the families and the ministry are high while the parents pointed to the same result for the internal obstacle represented by their preoccupation, working conditions and the lack of confidence that they were real partners with the school.

Based on the results of the study, many recommendations were made, including the necessity of activating Parents' Councils to be an effective tool for activating the partnership between the family and the school in Jordan.
\end{abstract}

Keywords: school-family partnership, parents' councils, partnership's obstacles, education, Parent Involvement, academic performance

\section{Introduction}

\subsection{What is Partnership?}

Partnership is an agreement where two or more people or groups work together toward mutual goals. Partnerships can be formal, informal, or even unspoken as long as they include people or groups working together. Most experts agree that a partnership must benefit both sides for it to be truly effective. When two parties come together for the common good of a school or to enhance student learning, we call this an educational partnership. (Cox-Petersen, 2011, p. 5)

Terminologically, it is identified as type of cooperation to achieve common objectives by sharing of roles and bearing responsibilities. Partnership is a tool to organize a stable relationship between two groups or more (Al-Sharif, 2016).

(Clark, 2008) Identifies partnership as the sense of community through its different social systems.

(Middlewood, 2009), argues that partnership is a work relation with mutual objectives and respect and ability to negotiate between participating parties, it requires information sharing and skills in making decisions, and consequently the accountability to assure achieving the quality of work.

(Mitchell, 2011)Defines it as "a working relationship that is committed to an organized character, to achieve common goals with a sense of mutual trust, a desire for successful, effective work, and a commitment to accountability. 
Procedurally, partnership known as the openness of the educational institution, i.e. the family, and getting out from narrow objectives through different communication means to join another part, i.e. school, in an organized way in order to achieve mutual objectives and act as one team to attain the educational, learning and social objectives that would be of benefits for students.

\subsection{Importance of School-Family Partnership}

Jordanian society viewed individual integrated development with a great interest, and this comes through the concentration on crystallizing the integral relationship between the most important two institutions: Family and school. Conformity and complementarity between the two institutions should be in the objectives, targets, practices and ideas related to the educational and instructional process of the young people. The more balanced the growth of the individual within these institutions, the more he satisfies his psychological, mental, social and educational needs and this will lead to the emergence of the required balanced personality which contribute in the construction of contemporary societies, This in its turn must be precisely accommodated with the strategies of educational development plans which lie on activation of the partnership between family and school in the society.

The School cannot act in isolation of the family which represent the first stone corner for both child and society, efforts should be excreted to narrow the gap between the two entities in order to develop the education and enhance its quality, this require the essential roles of the educational institutions to be well defined and articulated, in full consideration of the major role of the school in building the child's personality, knowledge capacity and skills to be a good citizen contributing in building his society (Jordan Ministry of Education, 2007)

The relation between home and school and the role of parents in developing their children's education has experienced greater degree of interest by thinkers and educational researchers in the last decades. Many educational systems in the developed countries consider this among the priorities because the child's family's environment and culture are sources of education that support the school education. Besides that, parents' participation in the education process has a great role in reducing the gap between children coming from different social and economic backgrounds, example: those who require care and their peers coming from ordinary social circumstances, parents' participation in the education process has also a major role in reducing the challenges facing students and threatening their thinking and aspirations particularly because of the technological boom that broke the cultural barriers separating the peoples (Al-Mahdi, 2015)

In this regard, researchers and different studies dealt with the partnership between family and school assured that the interactions between parents and child, particularly stimulating and enhancing practices of parents have important impacts on the academic development of the child and improving his behaviors and discipline at school, develop his skills performance and raising the quality of his knowledge (Topor, Keane, Shelton, \& Calkins, 2010).

There is range of views, regarding the partnership between family and school, Epstein theory and its six aspects has been developed through what is known as overlapping of influence areas, where it concentrates on interaction, communication, partnership between parents and school and its effect on the children's behavioral and educational levels. This is represented in: Parental (related to parents' supervision and their distinguished educational care), Interaction (through the relation between parents and school in terms of following up their children's educational affairs), Volunteerism (through parents and their role in sustaining voluntary actions and positive initiatives which actively enhance school development process), Decision making (means to allow parents to real partnership in decisions making which relates to their children's educational process), Learning at home (through parental following up to the concepts and skills been taught at school) and Cooperation (through reporting the parents with their children's behavioral and educational reality of facts, in order that cooperation can later be positive). (Epstein, Galindo, \& Sheldon, 2011).

Starting of 2006/2007, Ministry of Education in Jordan, put a draft to develop the performance of schools, in order to enhance cooperation, integration and coordination to maintain a partnership between family and school. The draft came under the title (The systematic Project to develop the performance of Directorate and schools). The developing process in this project functioned by forming four sub work groups in the school dealing with four sectors: students, staff, management and school's relations. In this context, there will be two parties in charge: the first is the school council consisted of number of teachers and the second is the parents who maintain non-traditional relationships with school through their active participation in Parents' Councils, here, school appreciation for these activities and participation in school decisions is indispensable (Radwan \& Masarwah, 2014).

Educational studies point out that the relation between family and school is essential because they both are in 
charge of raring and raising children and each of them plays a complementary role through compounding educational skills, monitoring behaviors and enhancing societal value through a well-defined objective work plan related to the educational process (Anasweh \& Al-Rashdan, , 2011).

Schools attempt, through educational reform standards, to keep pace with the desired development and to achieve the balance between school and home values to be in harmony from one side and to agree with the society values from the other side. This is reflected in the curriculum that employs concepts, educational standards, and through the methods of teachers, principals and school's staffs to consolidate and strengthen the relationship between school and family (Mustafa, 2014).

(Ateiyah, 2007) Argues that when schools ensure the maintenance of strong relation with parents is considered as one of comprehensive quality standards in education through involving in out-of-school activities.

Developed countries have paid special attention to involving parents in educational process, such as the United States of America and Japan where school provide many services, such as developing councils at schools where parents are involved in discussing educational issues (Yahyawi, 2016).

\subsection{Literature Overview}

According to the research conducted by (Bull, Brooking, \& Combell, 2008) on some primary and secondary schools in New Zealand, and focused on the partnership between school and family and how to activate such partnership, the parent's participation has an effect on the students' academic achievements and rising their creativity level in terms of knowledge and skills.

In their field study, (Al-Hawamdeh, Jaradat, \& Otoum, 2011) aimed at revealing the obstacles hindering the cooperation between school and local society in Jerash governorate whether this obstacles are related to the school or to local society. The study has been conducted on a sample of 200 schools' principals and parents from the local society. Results showed that the most prominent constrains related to school are: the excessive school workload, lack of active regulations and legislations and inability of schools to satisfy the society needs. Similarly, constrains related to the society from the perspective of administrative staff were: the individuals' conviction that there is no need for their services, lack of awareness about their role in the educational process and lack of knowledge about educational legislations.

(AWAD, 2012)Study aimed at activating the role of family in the educational process in the secondary school in Cairo governorate/Egypt in the light of the principles of partnership and identifying the roles and responsibilities of family in socialization in general and in the educational process in particular. It also aimed at revealing the methods of partnership between the two institutions and analyzing obstacles hindering the partnership between the family and the school, with an objective to set up the recommendations for activating the role of family in the educational environment. This study used the analytical descriptive methodology and reached many findings, such as: the obstacles of partnership would be individual, organizational or psychological, school must therefore act on a full scale to overcome these obstacles for the purpose of having close links with parents and this is by inviting them to participate in school activities and voluntarily perform society services. This study also found results related to the challenges facing family individually such as the prevailing traditions and beliefs that the school perform its learning and educational role independently.

(Laster, 2013)Aimed at her study to reveal the expected effects of parents and teachers on the students' capacities and their academic level improvement throughout setting active partnership between families and schools. Findings indicated that lack of interaction between family and school deepens the disagreements between students which form additional challenge due to the lack of active interaction. Moreover, the study found that there is inadequacy at the level of teachers experience pertaining to strengthening societal partnership.

(Lauren, 2014)Conducted a study aimed at identifying the effects of partnership between parents and school on reducing the negative effects resulting from digital technology in class rooms which is negatively affecting students' behaviors and ethical practices. This study conducted through a workshop concentrated on the necessity of attaining electronic safety, especially for the teenagers, in addition to know the meaning of the proper digital patriotic. The workshop used many methods to achieve the said purposes and found number of results, such as: The necessity for family and school to work as one team to reduce negative electronic risks by including it in the academic curricula. This can be implemented upon adopting the parents' suggestions to school where the latter should be fully equipped for this.

(Al-Moghrabi, 2015)Conducted a study aimed at identifying the partnership reality in governmental schools within Jerusalem city in the light of some international specialized patterns and to identify the ways of development from the prospective of school principals and parents. To achieve the objective of the study, random 
stratified sample was used and consisted of (41) male and female teachers and (1598) parents. The researchers followed the analytical descriptive survey methodology. She developed a questionnaire consisted of (58) items distributed on two categories followed by an open question suggesting some methods and mechanisms to develop a partnership between family and school. The results showed that the overall degree for the partnership between family and school from the perspective of male and female principals were high and intermediate from the prospective of male and female teachers and parents.

(Harris, 2016)Aimed at his study to review the social view of partnership between family and school and the effect of that on the academic achievement of students. In addition to the importance of the role of school counselors in deepening the partnership between families and schools and the need to take into consideration the demographic and cultural structure of students in schools for the purpose of active and not nominal partnership. The results showed that partnership as concept must include academic curricula. The study showed also that school counselors don't understand the intercultural issue and they concentrate on the local culture. Moreover, the study revealed that the school counselors are in need for training on communication skills with multicultural families.

(Netecki, 2015) Aimed in his study at identifying the integrated partnerships between families and schools, particularly at pre-school stage as a multidimensional study for the purpose of producing a high quality program regarding family partnership. The prominent results of the study are: The communication between teachers and parents are available at Mill Creek School in the United States of America targeted by the study. The study indicated that the school follows up everything about children in kindergarten stage and inform the parents. The parents' interactions were intermediate, particularly in terms of education and following up at home though attendance of meetings was high. In terms of volunteerism, especially at classrooms were high, whereas decision making was fluctuating.

Finally, most studies have concluded that the interaction between the Family and the School is considered as vital for all society members because of its positive role in understanding, solving problems, accesses to knowledge, developing of skills and catalyzing learning at children.

\subsection{Form of Interaction between School and Family}

In general, Interaction between the school and the family is maintained through but not limited to the following methodologies:

The Open Day: The Open day reflects the extent of organization and practical development of the school by inviting parents to participate in out-of-school activities by sending them invitations to attend (Amroni \& Qadouri, 2013).

Reports: Reports are sets of documents and information organized in a particular way about students' behaviors and academic performance sent to parents to enable them following up the strengths and weakness of their children (Ramadan, 2005).

Home visit: Home visits maintained by teachers to students, in order to know the students' environment is of successful ways in the western countries where it achieved great success in developing educational process when the two parties meet and coordinate about the best way to raise and instruct children and provide the advice needed (De Medeiros Rodrigues Reali \& Regina Maria Simoes Puccinelli Tancredi, 2004).

Parents' Councils: An invitation is sent to all parents wishing to participate in the Parents' Council at the beginning of the academic year where the objective of this council and the proper time for discussion of academic issues are determined. Such councils are formed of two major parties: Teachers and parents (Radwan \& Masarwah, 2014).

\section{Method}

Family and School aim at achieve the development and prosperity for children to secure a real desired education, therefore, organizing the relation between family and school is considered important to maintain proper educational process.

The researchers, and through their experience, noticed that there are traditional roles of the partnership's pattern between family and school. There is also a lack of interest in activating this partnership which is limited to the unrealistic role of Parents' Council. Moreover, the Jordanian family places the onus of all aspects of the educational process on the school and draws itself from being a key partner which negatively impacted the pattern of the societal partnership between the two major educational institutions.

Consequently, the outcomes of educational process have been negatively affected at the level of individuals, with 
taking into consideration that the educational sectors in the world operate under high competition with respect to development of partnership between family and school.

This study came to discover the real status of partnership between family and school in Jordan, a very important subject that has direct effect on the students' scholar achievement and skills' development, and to investigate the main requirements to activate the partnership between family and school in Jordan.

To do this, the two researchers decided to collect the needed information and awareness directly from the concerned people (school and Family) and get their thoughts and convictions on the following 2 questions:

- What is the reality of partnership between family and school from the perspectives of School and parents member of Parents' Councils in Jordan?

- What are the obstacles that may hinder the partnership between family and school in Jordan from the perspectives of Schools and parents member of Parents' Councils in Jordan?

For this, the two researchers adopted the qualitative methodology through conducting deep interviews using open questions giving the interviewed more space to express themselves

The Study tool (the interview questions document) was reviewed and attested by a number of arbitration professors, specialized in Pedagogy and Education Administration in Jordanian Universities, to identify the clarity, validity, accuracy and language of the interview's questions.

Two schools were selected, Irbid Secondary School for girls and Irbid Secondary School for boys. For this study, 9 persons among the staff of the two schools and 21 parents' members of the Parents' Councils were chosen. The interviews have been then conducted and voice recorded, the respondents' answers transcribed, the content deeply reviewed and classified using EXCEL and finally analyzed as shown in the below discussion.

\section{Analysis Results and Discussion}

Interviews with schools staff and parents members in Parent's councils were conducted and the discussions focused on the above main 2 questions.

The interviews have been then analyzed from both family and school perspectives and revealed the following findings for both questions:

Question 1: What is the reality of partnership between family and school from the perspective of principals and Parents members of Parents' Councils in Jordan?

Finding out the whole reality about this partnership is translated here on retrieving and analyzing the following aspects related to the interaction between the family and the school:

1. The level of existing interaction between family and school

2. The channels of interaction between family and school

3. The methods of interaction between family and school

\section{From School Perspective (Administrative Staffs):}

A total of 9 school administrators have been interviewed and their thoughts on the above aspects of interaction are classified and discussed below:

The following Table (1) shows the study findings related to the level of existing interaction between family and school in Jordan from the schools staffs' perspective,

Table 1. Level of interaction between family and school in Jordan from school staff perspective

\begin{tabular}{clcc}
\hline \multirow{2}{*}{ No. } & $\begin{array}{l}\text { What is the level of existing interaction between family and school from your } \\
\text { perspective? }\end{array}$ & Frequency & Percentage \\
\hline 1 & High and continuous interaction with parents & 5 & $55.56 \%$ \\
2 & Intermediate interaction due to large volume of management work. & 4 & $44.44 \%$ \\
\hline
\end{tabular}

In term of the Existing Interaction between the School and the Family, the majority, 5 school's staffs out of 9 (55\% of the interviewed individuals) believe on a high and continuous interaction between the two institutions while only 4 school's staffs ( $44 \%$ of the interviewed individuals) consider this interaction to be moderate and this is because of the high volume of their daily preoccupation and managerial tasks. 
This relatively equal result indicates that the governmental Schools interaction with parents in Jordan is in need to be activated, though the high load of work borne by the administrative staff. Moreover, the answers of respondents indicated that there is a gap in the relationship between the family and the school and this is again due to the same reason of their high load and management duties.

In this context, Mr. Ali, principle of the boys' school said that: 'My interaction with parents is limited due to above perception high load of duties and tasks required from me as principle. "Laila, principle of a girls' school, said: "I attempt to maintain continuous interaction with parents with all possible means." Ahmed, Secretary at boys' school said: "My interaction with parents are limited, it is restricted to sending letters and publications and if you ask me about the reason, I may say that parents are not concerned about their children, at all."

Based on the answers of the schools staffs, it is clear that they are not interested in the interaction with parents, and only a small portion of them do so. This may be attributed to lack of awareness of schools staff towards the importance of such interaction.

The following Table (2) shows the study findings related to the Channels of Interaction between family and school in Jordan from the schools staffs' perspective

Table 2. Channels of interaction between family and school in Jordan from the schools staffs' perspective

\begin{tabular}{clcc}
\hline No. & What are the channels of interaction between family and school? & Frequency & Percentage \\
\hline 1 & $\begin{array}{l}\text { Interaction with parents through phone calls, personal meetings or school } \\
\text { electronic site with possibility to use more than one channel. }\end{array}$ & 6 & $66.67 \%$ \\
2 & Interaction with parents through written letters sent with students. & 3 & $33.33 \%$ \\
\hline
\end{tabular}

The majority 6 School's staffs $(66.67 \%$ of the interviewed individuals) prefer the paper less channels of interaction shown above, while only 3 participant (33.33\% of the interviewed individuals) always communicate with the families through written letters

In this context, Alia, assistant principle at girls' school said that: "we use many channels to interact with parents, such as phone calls, printed letters sent with students. Moreover, we do activate our page on Facebook and we always welcome the parents' Suggestions". A counselor in boys' school said:" we only use phone calls to interact with parents, personally meet them and send them periodic bulletins". A female counselor named Iman said:" Frankly, we do interact with parents orally more than electronically."

Based on the feedbacks of the schools staffs, we notice that the traditional channels of interaction, such as: phone, personal meetings and printed materials are more used compared to electronic interaction which is still very limited, and this is attributed to the easiness of personal communications by summoning parents or talking to them on phone. We notice that there is a problematic issue in schools' not keeping pace with new means of communications and social media with the families and even not concerned in activating such means of interaction, moreover, the schools' staffs attributed this to the non-willingness of parents to adopt these channels of communication except a small portion of parents who prefer electronic interaction due to easiness and effectiveness.

The following Table (3) shows the study findings related to the Methods of Interaction between family and school in Jordan from the schools staffs' perspective:

Table 3. Methods of interaction between family and school from the perspective of school staff in Jordan.

\begin{tabular}{clcc}
\hline No. & What are the methods of interaction between family school and? & Frequency & Percentage \\
\hline 1 & $\begin{array}{l}\text { Interaction is done through Parents' Councils, out-of-class activities and annual } \\
\text { public meetings. }\end{array}$ & 4 & $44.44 \%$ \\
2 & Interaction with parents only done only through annual public meetings. & 5 & $55.56 \%$ \\
\hline
\end{tabular}

Here, we focus more on the face to face Methods of Interaction between the school and family in Jordan, 5 school's staffs (55.56\%. of the interviewed individuals) make this interaction with parents through annual public meetings only while the remaining 4 School's staffs (44.44\% of the interviewed individuals) interact with the families through Parents' Councils, out-of-class activities and annual public meetings.

In this context, a counselor in boys' school said: 'We Interact with and meet the parents face to face through the 
annual public meetings only", while Abeer, a counselor in girls' school said: "We activate our interaction with the parents through Parents' Councils and the annual public meetings".

Based on the feedbacks of the schools staffs, it appears that the most common method of face to face interaction with the parent is still the annual public meetings, the school is satisfied with some quarterly or annual public meetings with parents and the efforts for activating the Parents' Council is very limited and sometimes not existing. This is because of, as per the school, the shortage of time to organise the extracurricular activities, which is of course, if orgsnised, will be on the cost of completing the educational curriculum, this is beside the fact that the parents participating in the Parents' Councils are not activating the discussion agenda in the desired manner.

\section{From the Parents participating in the Parents' Council perspective:}

A total of 21 parents have been interviewed and their thoughts to the above aspect of interaction are classified and discussed below:

The following Table (4) shows the study findings related to the level of existing interaction between family and school in Jordan from the Parents participating in the Parents' Council perspective.

Table 4. Level of interaction between family and school in Jordan from parents' perspective

\begin{tabular}{clcc}
\hline \multirow{2}{*}{ No. } & What is the level of the existing interaction between family and school from & Frequency & Percentage \\
& your perspective? & 9 & $42.86 \%$ \\
\hline 1 & High and continuous interaction with school & 7 & $33.33 \%$ \\
2 & Intermediate interaction due to work circumstances. & 5 & $23.81 \%$ \\
3 & Low degree of interaction. & 5 \\
\hline
\end{tabular}

The majority ( 9 out of 21 ) of the interviewed parents $(42.86 \%$ of the interviewed individuals) believe on a high and continuous interaction between the two institutions, 7 parents (33.33\% of the interviewed individuals) consider this interaction to be moderate and this is because of their work conditions and only 5 parents $(23.81 \%$ of the interviewed individuals) see a low degree of interaction.

In this context and as a sample of parents' quotes on high and continuous interaction, "Hiyam" who is a mother and member in the Parents' Council said:" I come on continuous basis to attend the school gatherings and attend all the school meetings periodically. "Fatima", another mother said:" I didn't miss any meeting. I keep in touch with the school and always inquire about my daughter by contacting the principle and the counselor". Mr. Atif, father and member of school council said: "I contact the school on weekly basis so even there is no meeting". Another sample of parents' quotes on Intermediate interaction due to work circumstances, Nidaa, mother and member in school council said: "My participating in the meeting is intermediate because my job hinders me from attendance." Another father said:" My interaction with school regarding my son is limited because the school unfortunately doesn't encourage parents to interact in addition to my job conditions and distance preventing me from interacting with the school." Finally and as a sample of quotes on low degree of Interaction, one parent said:" My interaction with school is very low, I only visited the school once", another father said:" I visited the school in two occasions only because the school doesn't encourage parents to come".

Consequently, we notice that the level of existing interaction of parents participating in Parents' Councils with the school is in need of more activation, despite of the provision of good portion of parents so keen to interact on continuous basis. In this context, Parents still consider their partnership with the school is secondary and non-essential because the school in their view is responsible for raising up and educating their children and therefore there is no need to interact with the school staffs. Moreover, we noticed, through the answers of the interviewees, that there is a gap in the partnership between the family and the school, and that the working conditions of the parents are sometimes an obstacle to their communication.

The following Table (5) shows the study findings related to the Channels of Interaction between family and school in Jordan from the parents' perspective: 
Table 5. Channels of interaction between family and school in Jordan from parents' perspective

\begin{tabular}{clcc}
\hline No. & What are the channels of interaction between school and family? & Frequency & Percentage \\
\hline 1 & $\begin{array}{l}\text { Interaction with parents through phone calls, personal meetings or school } \\
\text { electronic site with possibility to use more than one channel. }\end{array}$ & 11 & $52.38 \%$ \\
2 & Interaction with parents through written letters sent by students. & 10 & $47.62 \%$ \\
\hline
\end{tabular}

The above table shows a relatively equal findings for parents interacting with the school through paper less channels of communication: phone calls, personal meetings or school's electronic site with possibility to use more than one channel (11 parents representing $52.38 \%$ of the interviewed individuals), and parents interacting with the school through written letters sent with the students (10 parents representing $47.62 \%$ of the interviewed individuals).

In this context and as a sample of parents interacting with the school through paperless channels quotes, a mother named "Huda" member of Parents' Council said, "I keep in touch with school by phone and I meet school principle and teachers at school meetings". Another sample of parents interacting with the school through written letters sent with the students quotes, Hasan, father of a student said:" I only attend school meeting when they send a notification with my son". Another parent, said:" I know nothing about my son's school except when he brings me an invitation for a meeting". Mr. Mohammed, father and member of school council said: "My daughter Aliyah brings letters and printed materials from school sent by the principle, I only can attend school meeting and ask about my daughter when my work conditions allow me so."

In the light of the forgoing, we notice that parents' interaction with school is still traditional, maintained through personal meeting and on phone, forming two main channels for interaction and communication, on the detriment of modern social media which are still very limited. Reciprocally, this is attributed according to most of parents to schools who discourage the interaction and do not activate modern communication channels.

The following Table (6) shows the study findings related to the Methods of Interaction between family and school in Jordan from the Parents' perspective:

Table 6. Methods of interaction between family and school in Jordan from parents' perspective

\begin{tabular}{clcc}
\hline No. & What are the methods of interaction between family and school? & Frequency & Percentage \\
\hline 1 & $\begin{array}{l}\text { Interaction is done through Parents' Councils, out-of-class activities and annual } \\
\text { public meetings. }\end{array}$ & 12 & $57.14 \%$ \\
2 & Interaction with parents done only through annual public meetings. & 9 & $42.86 \%$ \\
\hline
\end{tabular}

The above findings shows that interviewees interact with the school in different ways, 12 parents $(57.14 \%$ of the interviewed individuals) interact with the school through Parents' Councils, out-of-class activities and annual public meetings, while the 9 others (42.86\% of the interviewed individuals) make this interaction with the school through annual public meetings only,

In this context and as a sample of quotes of parents interacting with the school through Parents' Councils, out-of-class activities and annual public meetings, "Haifa", mother and member of school council said: "I used to participate in the school council activities and I participated in one-free-awareness- medicine-day", another mother said: "I attended the meeting the principal called for once in the first semester and one another in the second semester only", "Mohammed, father and member of school council said: "Probably, I attended only two meetings and they were related to discuss the results of the first semester". He added:" Parent's Council wasn't active at all."

\section{Question 2: What are the obstacles that may hinder the partnership between family and school in Jordan from the perspective of principals, Parents member of Parents' Councils?}

In this section we will try to draw the full picture about the obstacles preventing the activation of partnership between family and school again from both Perspectives: School and Parents, the above question was answered by the same group, again composed by 9 school administrators and 21 parents, their thoughts reviewed, grouped and analyzed as shown below:

\section{From School Perspective}


Table 7. Obstacles preventing the interaction between family and school from the perspective of school administrative staff in Jordan

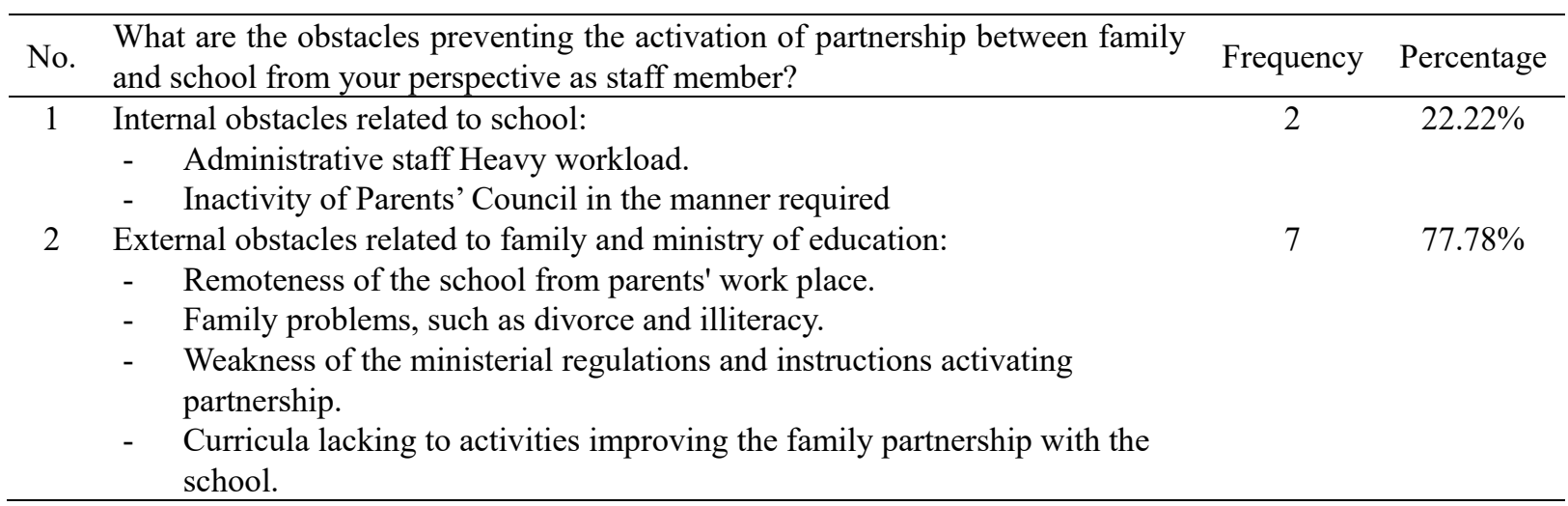

Here, the answers have been grouped into 2 groups of obstacles: internal obstacles related to the school and external obstacles related to the family and ministry of education, the internal obstacle include administrative staff heavy workload, inactivity of Parent's Council in the manner required, the external obstacle include remoteness of the school from parents' work place, family problems, such as divorce and illiteracy, weakness of the ministerial regulations and instructions activating partnership, curricula lacking to activities improving the family partnership with the school.

The above Table (7) shows that most of the obstacles are external to the school and mainly attributed to the family and the ministry, 7 school's staffs (77.78\% of the interviewed individuals) voted for the external obstacles while only 2 staffs ( $22.22 \%$ of the interviewed individuals) voted for the obstacles internal to the school.

In this context, a principal of girls' school said:" we are shocked by the environment and social circumstances of some students who overburdened by the results of poverty and divorce". She added: "absence of better concepts about volunteerism is a problem and we always try to deal objectively with the parents in this regard, we also observe the weakness of ministerial regulations, which enhance parent's partnership, we hear cracking, but we don't see grinding". Another principal of boys' school said:" We suffer of the involvement of parent in work and their neglegence to follow up their children. Sometimes we reiterate our request but no avail". He added: ministerial regulations exist, but the responsible for implementing these regulations, such as heads of educational development councils, consider the position as honor and prestige rather than assignment, therefore the minimum of these regulations are implemented."

Another administrative staff said: "we suffer of the lack of electronic interaction with parents. We call upon the ministry of education to provide access to the internet which will enable us to better interaction with parents". A school counselor in a girls' school said, "Some parents lack of awareness towards the need of their daughters, all the time busy, they don't follow up them." Another principal in a boys' school said:" we are very interested in activating our relation with parents, but the heavy workloads prevent us from moving ahead". He added, "Parents' Council at school is inactive, it is a mere in on paper, the reason is parents apathy."

Based on the above discussion, we notice the absence of an annual promotional planning at the school level towards the activation of partnership with parents which is supposed to positively reflect on the students' academic achievement. They hide behind heavy workloads which is no excuse because if there is an objective plan to activate school Parents Councils, workloads wouldn't be a barrier at all. Parents' Councils would be run smoothly and routinely and held 3-4 times yearly, this is not much but no success. Under this scenario, both parties: school and family, are accusing each other for the failure of partnership.

\section{From the Parents participating in the Parents' Council perspective:}

The same 21 interviewed parents have also expressed their points of view related the obstacles that hinder the partnership between family and school, their opinions are summarized in the following table (8) 
Table 8. Obstacles preventing the interaction between family and school from perspective of parents' members in Parents' Council

\begin{tabular}{|c|c|c|c|}
\hline No. & $\begin{array}{l}\text { What are the obstacles of partnership between family and school from } \\
\text { perspective as participating member in the Parents' Council? }\end{array}$ & Frequency & Percentage \\
\hline 1 & $\begin{array}{l}\text { Internal obstacles related to school, such as: busyness of parents in work and } \\
\text { difficult work conditions. }\end{array}$ & 5 & $23.81 \%$ \\
\hline 2 & Parents loss of trust in school & 5 & $23.81 \%$ \\
\hline 3 & $\begin{array}{l}\text { External obstacles related to school: } \\
\text { Inactivity of Parents' Council in the manner required }\end{array}$ & 3 & $\%$ \\
\hline 4 & School unresponsiveness to parents' suggestions and ideas. & 4 & 19. \\
\hline 5 & $\begin{array}{l}\text { External obstacles related to ministry of education, such as weakness of the } \\
\text { ministerial regulations and instructions activating partnership. }\end{array}$ & 3 & $14.29 \%$ \\
\hline 6 & Curricula lacking to activities improving family partnership with the school. & 1 & $4.76 \%$ \\
\hline
\end{tabular}

Here, the answers have been grouped into 6 groups of obstacles: internal obstacles related to the family and represented by the parent preoccupation and their difficult work conditions, Parents loss of trust in school. external obstacles related to school and mainly speak about the inactivity of Parents' Council in the manner required, school unresponsiveness to parents' suggestions and ideas, other external obstacles related to ministry of education and mainly focus on the weakness of the ministerial regulations and instructions to activate the partnership and finally the curricula lacking to activities that improve the family partnership with the school.

The most dominant answers are those related to the first 2 opinions: internal obstacles related to the family and represented by the parent preoccupation and their difficult work conditions and parents loss of trust in school. The parents try here to through the responsibility in a reciprocal manner to the school and the same idea can be also extracted from the remaining 4 opinions.

In this regard, father of a student said:" Honestly, we no more trust the school; it is just a secured place outside home." Another mother member in Parents' Council said:" I am a working woman and the council meetings' circumstances prevent me to attend every time". "Another mother, named Haifa said:" Lack of seriousness in the relation between teachers and mothers and the parents loss of trust in school remains the main impediment to the development and enforcement of partnership."

Answers of the parents participating in Parents' Councils indicate that their work circumstances and the remoteness of their work location impedes partnership. This justification would be reasonable because the employee leaving duties during work hours is not permissible for particular jobs. Moreover, changing of parents 'attitudes towards school and their lack of respect to teacher which ended by losing their social stature due to lifestyle changes and the globalization which imposes itself on educational and cultural aspects, all this have shaken the trust and over time turned to obstacle.

One mother said: "since teachers have started private tuitions, parents no more trust in school or in teachers' performance", she added: "We consider school only as a recognized institution where our children can obtain academic certificates". Another father said, "School always impedes partnership because it doesn't encourage parents to interact and the school's staff, makes you feel that they are always busy".

The inactivity of Parents' Council in the manner required and the weakness of the ministerial regulations and instructions activating partnership came also with a considerable percentage of responses. In this context, father of a student said: "I deem the ministry of education is not concerned about partnership at all". Imad, father of a student said:" I suggest that the ministry of education appoints an employee for each school or even two schools to be in charge of promoting the interaction file between family and school; I think it would be good idea but unfortunately, the ministry is falling behind."

The last Opinion related to Curricula lacking to activities improving family partnership with the school was not representative and only one parent spoke about that. In this regard, father of a student said: "maybe the nature of curriculum plays a role in discouraging partnership, I feel this when turning the pages of my children's' books."

The answers of the interviewees pointed to variety of external obstacles, particularly school unresponsiveness to parents' suggestions and ideas. At councils meetings, teachers start to complain of students and hold family the responsibility of failure, parents on their turn blame the school for the incompetency and poor learning achievements and misbehavior of their children. This widening the gap in the relation between school and family. As a result, Parents' Council has become a routine procedure in fulfillment of ministry of education regulations. 
In this regard, many schools have a blurred vision towards the objectives of Parents' Council due to lack of following up and evaluation from the ministry of education. Curricula should also concentrate on the partnership between school and family through out-of-school activities which can enhance the image of partnership because parents are the best partners in the educational process.

\section{Conclusion}

The current study agrees with (Al-Hawamdeh, Jaradat, \& Otoum, 2011) which refer to the obstacle hindering the interaction between school and society due to heavy workloads and inactivity of the ministerial regulations. Moreover, this study agrees with (AWAD, 2012) study that obstacles of partnership are attributed to schools' lack of interest towards activating the partnership and participation of parents in school activities and volunteerism actions. In addition, family cultural environment, mother working outside home, work conditions and negative parental relations prevent parents from interacting with school and limit their follow-up of their children. This study also agrees with (Netecki, 2015) study which indicated that interaction of parents with school was intermediate, particularly the following up of children and the failure to involve parents in decisions making.

\section{Recommendations}

In the light of the forgoing discussion, and through the interviews with the individuals of the study population and following up the study content, the following recommendations have been made:

- Building up a joint working group between family and school able to achieve educational objectives that positively reflect on the outcomes of educational process.

- Establishing a committee at schools, in charge of consolidating relationships with parents under the supervision of ministry of education who is supposed to support it, facilitate its assignments, follow it up and evaluate its actions.

- Frequent parents' visits to schools and teachers to parents, in order to consolidate and activate real partnership.

- Adopting the open-day methodology with an objective to involve parents in the programs and activities targeting the activation of their partnership with the school.

\section{References}

Al-Hawamdeh, M., Jaradat, \& Otoum, M. (2011). Obstacles of Cooperation between school and local community comparative study -Governorate of Jerash. Jerash for researches and Studies - Jordan, 456-472.

Al-Mahdi, O. (2015, December 13). Parents participation in Teaching their Children and Enhancing the Relationship between Home and School. Retrieved from http://ae.linkdin.com

Al-Moghrabi, S. (2015). Parents partnership with public schools in Jerusalem and ways of developing it in light of some specialized global models. Beer Zeit: Unpublished Master degree thesis, Beer Zeit University.

Al-Sharif, D. (2016). Fields of Effective Educational Partnership in the perspective of strategic plan for pre-university education 2014-2030,. Educational and Social Studies, Damascus, 22(1), 443-492.

Amroni, H. T., \& Qadouri, K. (2013). Reality of family supportive for some schools in Alwadi State. Second National Forum about communication and quality of life family, Qasidi University Merbah Warqalah, Algeria., 1-12.

Anasweh, S. S., \& Al-Rashdan, A. (2011). The role of Family and Islamic School in Building the Muslim Child Personality. Educational Sciences Studies, Jordan, 2112-2126.

Ateiyah, M. A. (2007). Comprehensive Quality and Curriculum. Amman: Dar Al-Manahej.

AWAD, M. A. (2012). Activating the role of family in Educational Process in Secondary Stage in the Light of Partnership Principle. Education Magazine, AlAzhar University, Egypt (151) Part 4, 453-509.

Bull, A., Brooking, K., \& Combell, R. (2008). The development of Professional Successful Home- school Partnership. Minstry of Education-Newzland.

Clark, D. (2008). School as Learning Communities: Transforming Education. London: Cassell.

Cox-Petersen, A. (2011, p. 5). Educational partnership. London: SAGE Publishing.

De Medeiros Rodrigues Reali, A. M., \& Regina Maria Simoes Puccinelli Tancredi, R. M. (2004). School- Family Relationship: Some lessons from a teachers - Professional development Program. Harvard Family Research Project, 19. 
Epstein, J. L., Galindo, C. I., \& Sheldon, S. B. (2011). Levels of Leadership: Effects of district and school leaders on the quality of school programs of family and community involvement. Educational Administration Quarterly, 47(3), 462-495. https://doi.org/10.1177/0013161X10396929

Harris, P. (2016). School counsellor involvement in Partnership with families of color: A social cognitive perspective. Virginia: unpublished Phd, The college of William. http://dx.doi.org/10.21220/W4Z595

Jordan Ministry of Education. (2007). Instructions of Parents' Councils in public and private schools. Amman, Jordan.

Laster, L. (2013). The percievd Influence of Divergent parents and teacher perceptions student abilities on students and the establishme of Effective Family-School Partnebrship. Arkansas: Unpublished Phd, University of Arkansas,USA.

Lauren, M. (2014). Reducing Cyber Victimization through Home and School Partnership. Hawai: Unpublished phd of Philosophy, University of Hawai.

Middlewood, D. (2009). Mangament External Relations in Schools and Colleges. London: Paul Chapman, 111-129.

Mitchell, M. (2011, October 11). Family-School Partnerships for the 21st Century. Retrieved from https://www.psychologytoday.com

Mustafa, A. (2014). Education Strategies and Norms Based -Learning: Future Vision. National Workshop Conference for Curricula Requirements, Faculty of Education, University of Damascus, 180-232.

Netecki, E. (2015). Integrated School-Family Partnership in Preschool: Building Quality Involvement through Multidimensional Relationships. School Community Journal, 25(2), 195-219.

Radwan, A., \& Masarwah, O. (2014). reluctance of parents to participate in Parents' Councils and the effect on school violence. Al-Najah University Magazine for researches (For Humanitarian Sciences), 28(3), 642-663.

Ramadan, M. J. (2005). Fields of child education in family from integral prospective. Cairo- Egypt: World of Books.

Topor, D., Keane, S., Shelton, T., \& Calkins, S. (2010). Parent involvement and student academic performance: A multiple mediational analysis. PubMed Central (PMC),USA.Gov, 183-191. https://doi.org/10.1080/10852352.2010.486297

Yahyawi, N. (2016). Participation of the family to School and the integration of Relationship between them. University of Baskarah, Algeria, 112-123.

\section{Copyrights}

Copyright for this article is retained by the author(s), with first publication rights granted to the journal.

This is an open-access article distributed under the terms and conditions of the Creative Commons Attribution license (http://creativecommons.org/licenses/by/4.0/). 